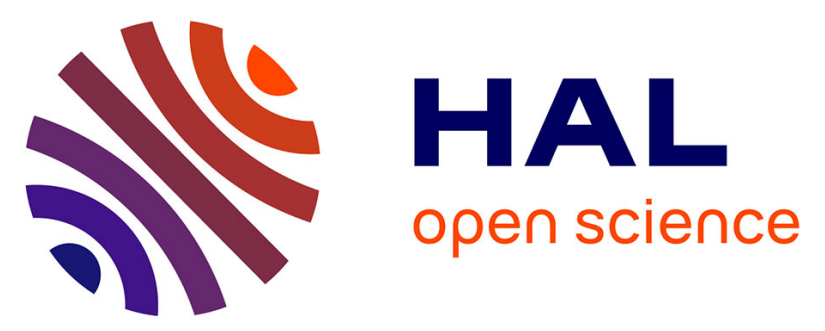

\title{
Influence of the strontium content on the performance of La1-xSrxMnO3/Bi1.5Er0.5O3 composite electrodes for low temperature Solid Oxide Fuel Cells
}

Martin Pajot, Victor Duffort, Edouard Capoen, Anne-Sophie Mamede, Rose-Noelle Vannier

\section{To cite this version:}

Martin Pajot, Victor Duffort, Edouard Capoen, Anne-Sophie Mamede, Rose-Noelle Vannier. Influence of the strontium content on the performance of La1-xSrxMnO3/Bi1.5Er0.5O3 composite electrodes for low temperature Solid Oxide Fuel Cells. Journal of Power Sources, 2020, Journal of Power Sources, 450, pp.227649. 10.1016/j.jpowsour.2019.227649 . hal-02428599

\section{HAL Id: hal-02428599 \\ https://hal.science/hal-02428599}

Submitted on 4 Jan 2021

HAL is a multi-disciplinary open access archive for the deposit and dissemination of scientific research documents, whether they are published or not. The documents may come from teaching and research institutions in France or abroad, or from public or private research centers.
L'archive ouverte pluridisciplinaire HAL, est destinée au dépôt et à la diffusion de documents scientifiques de niveau recherche, publiés ou non, émanant des établissements d'enseignement et de recherche français ou étrangers, des laboratoires publics ou privés. 


\title{
Influence of the Strontium Content on the Performance of $\mathrm{La}_{1-\mathrm{x}} \mathrm{Sr}_{\mathrm{x}} \mathrm{MnO}_{3} / \mathrm{Bi}_{1.5} \mathrm{Er}_{0.5} \mathrm{O}_{3}$ Composite Electrodes for Low Temperature Solid Oxide Fuel Cells
}

Martin Pajot, ${ }^{\mathrm{a}}$ Victor Duffort ${ }^{\mathrm{a} *}$, Edouard Capoen, ${ }^{\mathrm{a}}$ Anne-Sophie Mamede, ${ }^{\mathrm{a}}$ Rose-Noëlle

Vannier $^{\mathrm{a}}$

${ }^{a}$ Univ. Lille, CNRS, ENSCL, Centrale Lille, Univ. Artois, UMR 8181 - UCCS - Unité de Catalyse et Chimie du Solide, F-59000, Lille, France

\begin{abstract}
The possibility to use bilayer electrolytes based on bismuth oxide conductors should lead to a drastic decrease of solid oxide fuel cell (SOFC) operation temperature and calls for a reevaluation of some of the parameters optimized for high temperature applications. In this work we reinvestigate the promising $\mathrm{La}_{1-\mathrm{x}} \mathrm{Sr}_{\mathrm{x}} \mathrm{MnO}_{3} / \mathrm{Bi}_{2-\mathrm{x}} \mathrm{Er}_{\mathrm{x}} \mathrm{O}_{3}$ (LSM/ESB) composite electrodes, varying the strontium content from $\mathrm{x} \sim 0.2$, the typical high temperature LSM composition, to evaluate the optimum composition. Increasing the strontium content up to $\mathrm{x}=$ $0.4-0.5$ leads to a $14 \%$ decrease of the activation energy, resulting in a $50 \%$ decrease in the polarization resistance of symmetric cells at $500{ }^{\circ} \mathrm{C}$ compared to the traditional $\mathrm{La}_{0.85} \mathrm{Sr}_{0.15} \mathrm{MnO}_{3}$ composition with similar microstructure. The electrode performance is deteriorated by further increase in the strontium content. Based on surface composition, investigated by low energy ion scattering, we show that the SrO surface segregation proposed as the main deterioration mechanism for LSM based HT-SOFC is not an issue below $800{ }^{\circ} \mathrm{C}$. Furthermore, we propose that the increase in performance is related to the decrease of cationic vacancies in LSM observed for high strontium content, which may help the oxygen dissociation and surface transport.
\end{abstract}

Keywords: Low temperature solid oxide fuel cells; Stabilized bismuth oxides; Lanthanum strontium manganese oxides. 


\section{Introduction}

Solid Oxide Fuel Cells (SOFCs) are key components in the transition towards new energy sources with reduced carbon emissions. Due to their ability to convert the chemical energy stored in hydrogen into electrical and thermal energy with a $90 \%$ efficiency $^{1}$ without the need for noble metal catalyst, SOFCs are a corner stone in the development of hydrogen as an energy vector. However, the current technology based on yttrium stabilized zirconia (YSZ) electrolytes requires high $\left(>700{ }^{\circ} \mathrm{C}\right)$ operating temperatures, ${ }^{2}$ resulting in costly engineering, long startup time and reduced life span. The development of affordable, flexible and sustainable SOFCs based on more conductive electrolyte materials would greatly facilitate the integration of renewable energies into the power grid and allow applications in the field of transportation.

Decreasing the operating temperature can be achieved through two approaches; optimization (electrolyte thickness, electrode microstructure) of the high temperature cells or the design of cells using more efficient materials. The mediocre ionic conductivity of YSZ typically limits the operating temperature around $700{ }^{\circ} \mathrm{C}$, even with very thin electrolytes. On the other hand, it was shown that stabilized ceria and stabilized bismuth oxides, two very good families of oxide ion conductor plagued with stability issues under fuel conditions, could be combined to produce electrolytes with satisfactory performances at temperature as low as $350{ }^{\circ} \mathrm{C}^{3}$ This research spurred interest in the search for new electrodes able to perform at reduced temperature such as the perovskite $\mathrm{Ba}_{0.5} \mathrm{Sr}_{0.5} \mathrm{Co}_{0.8} \mathrm{Fe}_{0.2} \mathrm{O}_{3-\delta}{ }^{4}$ or the pyrochlore $\mathrm{Bi}_{2} \mathrm{Ru}_{2} \mathrm{O}_{7}{ }^{5}$

$\mathrm{La}_{1-\mathrm{x}} \mathrm{Sr}_{\mathrm{x}} \mathrm{MnO}_{3}$ (LSM) is one of the most studied high temperature SOFC cathode material. ${ }^{6-8}$ Due to its purely electronic conductivity it needs to be used in composite with oxide ion conductors, typically YSZ, to provide some level of ionic conduction. The reaction 
of oxygen reduction then takes place at the triple phase boundary (TPB), i.e. at the junction of the electronic conductor (LSM), the ionic conductor (YSZ) and gaseous oxygen. After many years of research on these composite cathodes the exact mechanism of the oxygen reduction reaction (ORR) is still debated, but it is generally accepted that the main limiting steps are the migration of oxygen species on the surface of LSM and their transfer into the stabilized zirconia. ${ }^{9,10}$ In the case of LSM/YSZ composite electrodes, it was shown that increasing the strontium content in $\mathrm{La}_{1-\mathrm{x}} \mathrm{Sr}_{\mathrm{x}} \mathrm{MnO}_{3}$ to about $\mathrm{x} \approx 0.5$ was both beneficial for the electronic conductivity and for the polarization resistance. ${ }^{10-12}$ However compositions in the range $\mathrm{x}=$ $0.15-0.2$ are typically selected because of mechanical compatibility with YSZ. ${ }^{13,14}$ Moreover, a small A-site deficiency is usually introduced to prevent the formation of $\mathrm{La}_{2} \mathrm{Zr}_{2} \mathrm{O}_{7}$ and $\mathrm{SrZrO}_{3}{ }^{15,16}$

The benefits of combining LSM with highly conductive and ORR active stabilized bismuth oxide phases rather than the typical YSZ have been identified early on. ${ }^{17-22}$ As expected, the overall ORR mechanism is similar for ESB and YSZ composite electrodes since both phases are pure ionic conductors. These electrodes became interesting candidates for low temperature applications when it was found that using erbium stabilized bismuth oxide (ESB) at both the cathode and electrolyte led to a $60 \%$ decrease in the cathodic area specific resistance (ASR) over the same electrode deposited on stabilized ceria. ${ }^{23}$ Full cell test of these electrodes on $\mathrm{ESB} / \mathrm{GDC}$ bilayer electrolyte demonstrated an impressive $1 \mathrm{~W} \mathrm{~cm}^{-2}$ at $650{ }^{\circ} \mathrm{C}^{23}$ Several groups subsequently studied the stability and optimized the performances of this composite cathode by modifying the ESB/LSM ratio or the microstructure of the electrode by infiltration and nanoscaling. ${ }^{24-29}$ In all these studies the strontium content of the $\mathrm{La}_{1-\mathrm{x}} \mathrm{Sr}_{\mathrm{x}} \mathrm{MnO}_{3}$ phases was kept close to $\mathrm{x} \approx 0.2$, i.e. the optimized composition for mechanical compatibility with YSZ in high temperature SOFCs. 
In this paper, differently from previous work on LSM/ESB composite electrodes, we explore the whole solid solution of $\mathrm{La}_{1-\mathrm{x}} \mathrm{Sr}_{\mathrm{x}} \mathrm{MnO}_{3}$, rather than focusing on $\mathrm{x} \approx 0.2$, in order to evaluate if the optimum strontium concentration for low temperature LSM/ESB electrodes is different from the optimized composition of high temperature LSM/YSZ electrodes. We synthesized $\mathrm{La}_{1-\mathrm{x}} \mathrm{Sr}_{\mathrm{x}} \mathrm{MnO}_{3}$ with $\mathrm{x}=0.15,0.3,0.4,0.5,0.6,0.8$ by solid state reaction and characterized the structure, the oxygen stoichiometry and the conductivity as function of temperature under air atmosphere. We chose $\mathrm{Bi}_{1.5} \mathrm{Er}_{0.5} \mathrm{O}_{3}$ rather than the more commonly used $\mathrm{Bi}_{1.6} \mathrm{Er}_{0.4} \mathrm{O}_{3}$, because despite a small decrease in ionic conductivity induced by the higher erbium content, this phase offers a much higher stability under $600{ }^{\circ} \mathrm{C} .{ }^{30,31}$ The LSM/ESB electrode composition and thickness were optimized by minimizing the area specific resistance (ASR) on $\mathrm{LSM} / \mathrm{ESB}|\mathrm{ESB}| \mathrm{LSM} / \mathrm{ESB}$ symmetric cells with $\mathrm{x}=0.15$. These optimized conditions were then used to systematically study the influence of the strontium content on the ASR of the composite electrode. Furthermore, we use low energy ion scattering (LEIS) to study the surface composition of $\mathrm{La}_{1-\mathrm{x}} \mathrm{Sr}_{\mathrm{x}} \mathrm{MnO}_{3}$ with $\mathrm{x}=0.15$ and 0.4 , showing that differently from literature data reported at high temperature, $\mathrm{SrO}$ segregation is not an issue below $800{ }^{\circ} \mathrm{C}$.

\section{Experimental}

\subsection{Material preparation.}

$\mathrm{Bi}_{1.5} \mathrm{Er}_{0.5} \mathrm{O}_{3}$ (ESB) was synthesized following a previously described protocol. ${ }^{32}$ In a typical synthesis about $10 \mathrm{~g}$ of $\mathrm{Bi}_{2} \mathrm{O}_{3}$ (previously decarbonated at $600{ }^{\circ} \mathrm{C}$ ) and $\mathrm{Er}_{2} \mathrm{O}_{3}$ (previously annealed at $900{ }^{\circ} \mathrm{C}$ ) with a Bi:Er molar ratio of 3:1 were dissolved separately in hot concentrated nitric acid (67 wt.\%) to approximately $0.5 \mathrm{~g} \mathrm{~L}^{-1}$. The nitrate solutions were then mixed and slowly added to a $\mathrm{pH}=9$ ammonia buffer solution $(0.1 \mathrm{M})$ at $50{ }^{\circ} \mathrm{C}$ under vigorous stirring. The $\mathrm{pH}$ of the solution was maintained throughout the experiment by addition of $8 \mathrm{M}$ ammonia solution. The suspension was then kept under stirring at $50{ }^{\circ} \mathrm{C}$ for 1 
$\mathrm{h}$; the pinkish precipitate was collected by centrifugation and dried overnight at $100{ }^{\circ} \mathrm{C}$ and finally heated in gold crucibles $\left(5^{\circ} \mathrm{C} \mathrm{min}^{-1}\right)$ at $740{ }^{\circ} \mathrm{C}$ for $12 \mathrm{~h}$.

$\mathrm{La}_{1-\mathrm{x}} \mathrm{Sr}_{\mathrm{x}} \mathrm{MnO}_{3}(\mathrm{LSM})$ with $\mathrm{x}=0.15,0.3,0.4,0.5,0.6,0.8$ were synthetized by solid state reaction method. Stoichiometric amounts of the precursors $\mathrm{La}_{2} \mathrm{O}_{3}$ (stored at $900{ }^{\circ} \mathrm{C}$ ), $\mathrm{SrCO}_{3}$ (stored at $100{ }^{\circ} \mathrm{C}$ ) and $\mathrm{MnO}$ were intimately ground with mortar and pestle. The desired phases were obtained after several heat treatments from $900{ }^{\circ} \mathrm{C}$ to $1400{ }^{\circ} \mathrm{C}$ for $12 \mathrm{~h}$ with intermediate grindings.

The particle size was reduced by ball milling in acetone media for $2 \mathrm{~h}$ at $1000 \mathrm{rpm}$. The milled powders were then used directly for the ink preparation (see below) or isostatically pressed $(200 \mathrm{MPa})$ into pellets. ESB was sintered at $850^{\circ} \mathrm{C}$ for $12 \mathrm{~h}$ to be used as electrolytes and the various LSM compositions were sintered at $1400{ }^{\circ} \mathrm{C}$ for resistivity measurements.

\subsection{Ink elaboration and deposition.}

Electrodes deposition was carried out following a standard protocol. ${ }^{33}$ To prepare the inks, the LSM and ESB powders were ball milled with 2 wt.\% of dispersant (T01 Cerlase) in ethanol for $5 \mathrm{~h}$ at $500 \mathrm{rpm}$. After evaporation of the ethanol, the powder was stirred with a binder (Mixtrio, EC3, Ferro Couleurs, France, 65 wt.\%) and homogenized using a threecylinder roll mill. In a second step, symmetric cells made of a $10 \mathrm{~mm}$ diameter and $1.8 \mathrm{~mm}$ thickness ESB dense electrolyte were prepared by deposition of the ink on each face of the ESB pellet using a DEK 248 screen-printer. To allow subsequent layer deposition, the sample was dried at $80{ }^{\circ} \mathrm{C}$ between each deposition. Finally, the as prepared symmetric cells were annealed at $500{ }^{\circ} \mathrm{C}$ for $1 \mathrm{~h}$ to remove the organics and successively at $800{ }^{\circ} \mathrm{C}$ for $2 \mathrm{~h}$ with a 5 ${ }^{\circ} \mathrm{C} \min ^{-1}$ heating rate between each plateau.

\subsection{Characterization techniques.}


Powder X-ray diffraction (PXRD) patterns were recorded on Bruker D8 diffractometers equipped with Lynx-Eye Position Sensitive detectors, in the $\theta-\theta$ implementation of the Bragg-Brentano geometry using $\mathrm{Cu}-\mathrm{K}_{\alpha}$ radiation and a nickel $\mathrm{K}_{\beta}$ filter. High temperature patterns were recorded using an Anton Paar HTK1200 chamber under a flow of dry air. Structural information was extracted using Rietveld analysis within the FullProf software suite. ${ }^{34}$

Thermogravimetric analyses (TGA) were performed in platinum crucibles using a Setaram Setsys thermobalance equipped with a differential thermal analysis (DTA) sample rod under argon or air atmospheres. Buoyancy and convection effects were accounted for using a proper blank in order to resolve the small mass losses due to oxygen stoichiometry evolution in LSM materials.

Electrochemical impedance spectra (EIS) were collected using a Solartron 1260 frequency response analyzer at open circuit voltage with a $50 \mathrm{mV}$ sinusoidal excitation in the $10^{6}-0.1 \mathrm{~Hz}$ frequency range on symmetric cells. Gold grids were used as current collectors. Area specific resistances (ASR) were obtained by fitting the spectra with the Zplot (Scribner Associates) software and normalized to the total surface of the electrodes. Resistivity measurements were performed on dense LSM pellets using linear 4-probe technique and a Biologic SP150 galvanostat. Both types of samples were heated in tubular furnaces using homemade measurement rigs. Thermal stability was checked by taking two measurements at 15 min intervals after a fixed $(1 \mathrm{~h})$ stabilization time.

The electrodes microstructure was studied using a Hitachi S3400N scanning electron microscope (SEM) in backscattered electron (BSE) mode in order to obtain a good contrast between the LSM (dark) and ESB (clear) phases. 
Low Energy Ion Scattering (LEIS) measurements were performed in a Qtac100 instrument (IONTOF GmbH). The samples, high density pellets with freshly ground surface annealed in air at $800{ }^{\circ} \mathrm{C}$ for $72 \mathrm{~h}$, were cleaned with an oxygen plasma at room temperature and analysed using a $5 \mathrm{keV} \mathrm{Ne}$ primary ion beam directed perpendicularly to the target surface. The surface, sub surface and bulk spectra were obtained at different ionic dose: $3.6 \times 10^{14}, 9.5 \times 10^{15}$ and $6.0 \times 10^{16}$ ion $\mathrm{cm}^{-2}$, respectively.

\section{Results and discussion}

\subsection{Raw materials characterization.}

The purity of the different compounds was checked by PXRD. The pattern of the coprecipitated $\mathrm{Bi}_{1.5} \mathrm{Er}_{0.5} \mathrm{O}_{3}$ (Fig. S1-a) is perfectly explained by the expected fluorite-type structure $(F m \overline{3} m)$ with a $=5.4852(1) \AA$ in good agreement with previously reported values. ${ }^{32}$ The ionic conductivity of the prepared ESB was verified on dense pellet (Fig. S1-b).

The structure of all the LSM compositions studied here are based on the simple cubic perovskite structure $(\operatorname{Pm} \overline{3} \mathrm{~m})$. The 12-coordinated A-site is occupied by statistically distributed $\mathrm{Sr}^{2+} / \mathrm{La}^{3+}$ cations and manganese atoms are located in the B-site. Small discrepancies are observed in the reported structural parameters throughout the literature due to the influence of the synthesis and/or annealing conditions of LSM. In our case, samples with a strontium content of $\mathrm{x}=0.4$ and lower crystalize with a hexagonal distortion $(R \overline{3} c)$ while samples with a strontium content of $\mathrm{x}=0.5$ and higher are orthorhombic (Pnma). This change of symmetry is clearly evidenced by the splitting of the reflection located at $2 \theta=47^{\circ}$ (Fig. 1-a) for $x \geq 0.5$. In order to facilitate the comparison between the two symmetries, the cell parameters are reported in the pseudo-cubic cell corresponding to the aristotype (Fig. 1b). 
The Goldschmidt factors of the $\mathrm{La}_{1-\mathrm{x}} \mathrm{Sr}_{\mathrm{x}} \mathrm{MnO}_{3}$ series evolve from 0.95 for $\mathrm{x}=0$ to 1.04 for $\mathrm{x}=1$, hence for La-rich compositions the A-site cations are smaller than the 12coordinated site in an ideal perovskite and the evolution of the cell parameters are dominated by the decrease of the manganese radius as it is oxidized from $\mathrm{Mn}^{3+}$ to $\mathrm{Mn}^{4+}$ through the substitution of $\mathrm{La}^{3+}$ by $\mathrm{Sr}^{2+}$. Conversely, the A-site cations of Sr-rich compositions are too big to fit in the 12-coordinated site of the cubic perovskite structure and $\mathrm{SrMnO}_{3}$ is expected to crystalize in a hexagonal perovskite structural type. This explains the growth of the impurity peaks visible on the XRD pattern of $\mathrm{La}_{0.4} \mathrm{Sr}_{0.6} \mathrm{MnO}_{3}$ and $\mathrm{La}_{0.2} \mathrm{Sr}_{0.8} \mathrm{MnO}_{3}$. Using Rietveld refinement we were able to estimate that these peaks account for about 2 and 6 wt.\% of $\mathrm{SrMnO}_{3}$ with a $4 \mathrm{H}$-hexagonal perovskite structure $\left(P 6_{3} / m m c\right)$. This impurity is usually associated to high temperature synthesis of Sr-rich LSM oxides. However due to the low levels of impurity we kept these samples rather than using a different synthetic route that could potentially result in a very different microstructure.
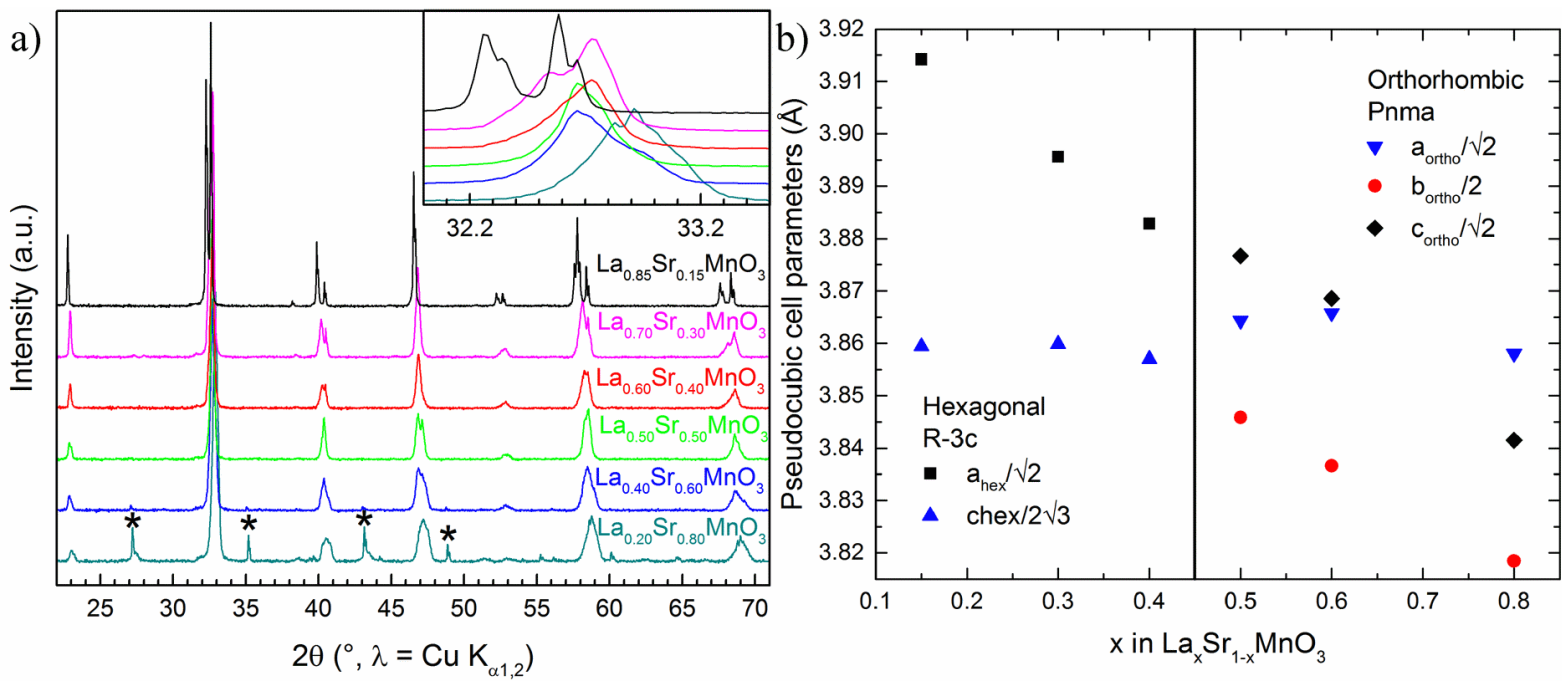

Figure 1: a) PXRD patterns of $\mathrm{La}_{1-x} \mathrm{Sr}_{x} \mathrm{MnO}_{3}$ showing good purity for $x=0.15-0.5$. For $x=0.6$ and 0.8 a small contamination of about 2 and 6 wt.\% respectively, of 4 H-hexagonal perovskite evidenced by the * symbols. The upper right inset shows a magnification of the most intense peaks and b) pseudo-cubic cell parameters evolution as a function of the strontium content. 
The main reason explaining the discrepancies observed throughout the LSM literature is probably an insufficient characterization of the oxygen overstoichiometry of these oxides. Due to oxidation of trivalent manganese ions, these oxides can readily pick up small quantities of oxygen depending on the composition or thermal treatment history. Hence a more accurate way to write the LSM formula is $\mathrm{La}_{1-\mathrm{x}} \mathrm{Sr}_{\mathrm{x}} \mathrm{MnO}_{3+\delta}$. However, the presence of interstitial oxygen was not seen by neutron diffraction showing that the oxidation mechanism did not proceed through oxo anions insertion but resulted in cationic vacancies. ${ }^{35}$ Thus, from a structural point of view, the accurate formula should be $\left(\mathrm{La}_{1-\mathrm{x}} \mathrm{Sr}_{\mathrm{x}} \mathrm{Mn}\right)_{1-\mathrm{y}} \mathrm{O}_{3}$ with all oxygen sites fully occupied and a cationic vacancy concentration $y=1-3 /(3+\delta \dot{i}) \dot{i}$. As will be shown later, this mechanism has important implications on the surface composition of LSM, however for clarity reasons, the initial writing $\mathrm{La}_{1-\mathrm{x}} \mathrm{Sr}_{\mathrm{x}} \mathrm{MnO}_{3+\delta}$ was used. A more detailed discussion on the oxidation mechanism by cationic vacancy formation, including the mathematical treatment necessary to the evaluation of the manganese average oxidation number by TGA, is given in the supplementary data.

Based on previous work showing that stoichiometric (i.e. $\delta=0$ ) samples were obtained by annealing $\mathrm{La}_{1-\mathrm{x}} \mathrm{Sr}_{\mathrm{x}} \mathrm{MnO}_{3+\delta}$ compositions with $\mathrm{x} \leq 0.5$ at $900{ }^{\circ} \mathrm{C}$ under argon atmosphere, ${ }^{36,37}$ we evaluated the oxygen overstoichiometry of our samples by thermal analysis under argon (Fig. 2). While the three hexagonal oxides exhibit well defined step-like mass losses, orthorhombic samples with $\mathrm{x}=0.5,0.6$ show almost no irreversible mass variation. This clearly relates the hexagonal symmetry to the oxygen overstoichiometry. Moreover we verified that argon annealed samples were all orthorhombic as previously decribed. ${ }^{36}$ In the case of $\mathrm{La}_{0.4} \mathrm{Sr}_{0.6} \mathrm{MnO}_{3}$ and $\mathrm{La}_{0.2} \mathrm{Sr}_{0.8} \mathrm{MnO}_{3}$, the higher oxidation state of manganese offers less resistance to the reduction and the small mass loss for temperature higher than $700{ }^{\circ} \mathrm{C}$ reflects the formation of understoichiometric oxides $(\delta<0)$. Interestingly while the process is reversible for $\mathrm{x}=0.6$ a small irreversibility is observed for $\mathrm{x}=0.8$. 


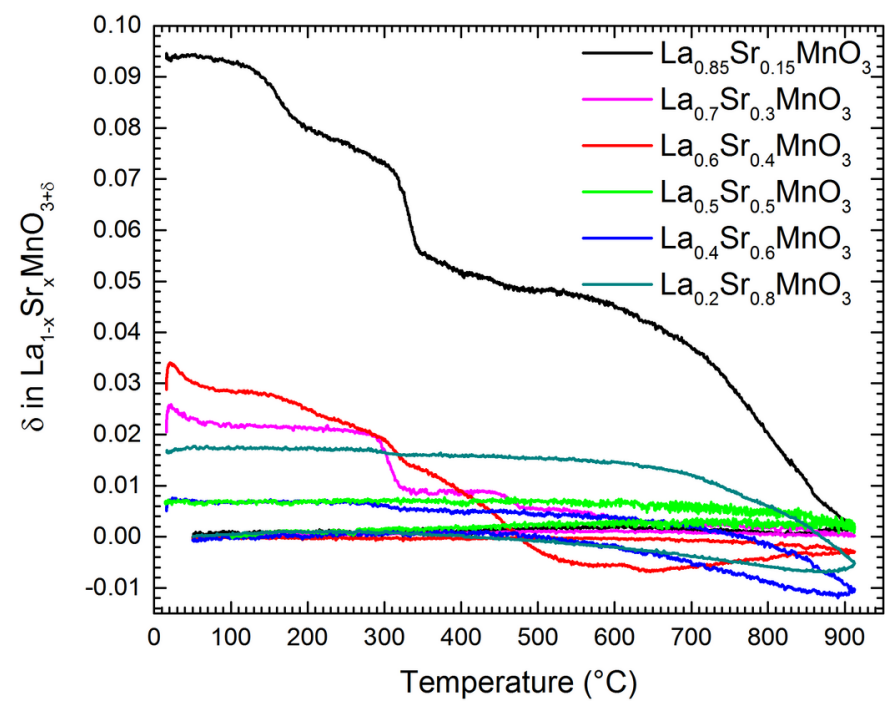

Figure 2: Determination of the oxygen overstoichiometry by TGA of the various LSM compositions under argon atmosphere.

Since electrical conductivity of LSM materials is influenced by the oxygen stoichiometry, it was measured for each sample under air to simulate the conditions of the ASR evaluation (Fig. 3). In a first step, we checked that the oxygen stoichiometry of the samples does not evolve when heated under air in the temperature range considered for electrochemical performance evaluation, i.e. RT $-800^{\circ} \mathrm{C}$. This was confirmed by the absence of irreversible mass variations for all the compositions under air by thermogravimetry as reported in Figure S2. The high temperature electronic conductivity of these materials is quite complex due to the interplay of carrier concentration, magnetic interaction and structure. As shown in Figure 3, the conductivity increases progressively with the strontium content up to $\mathrm{x}$ $=0.6$. Despite the temperature dependence of $\log (\sigma \mathrm{T})$ not being exactly linear we observe a decrease of the activation energy with increasing strontium content, from $0.17 \mathrm{eV}$ for $\mathrm{x}=0.15$ to $0.05 \mathrm{eV}$ for $\mathrm{x}=0.4$. This behavior is typical of heavily doped semiconductors, where the increase in charge carrier usually triggers a change from semiconductor to a metallic behavior. ${ }^{38}$ As expected ${ }^{39,40}$ metallic behavior is observed for $\mathrm{x}>0.175$ as evidenced by the change of slope below $100{ }^{\circ} \mathrm{C}$ for $\mathrm{x}=0.3$ and 0.4 . In our case, however, the metallic behavior 
does not seem to survive to the disappearance of the ferromagnetic order reported around 90 ${ }^{\circ} \mathrm{C}$ for these two compositions. Further increase in Sr-content tends to decrease the Curie point of LSM which explains why the transition is not seen for $\mathrm{x} \geq 0.5 .{ }^{39,40}$ The relevant parameters for all compositions are summarized in Table 1.

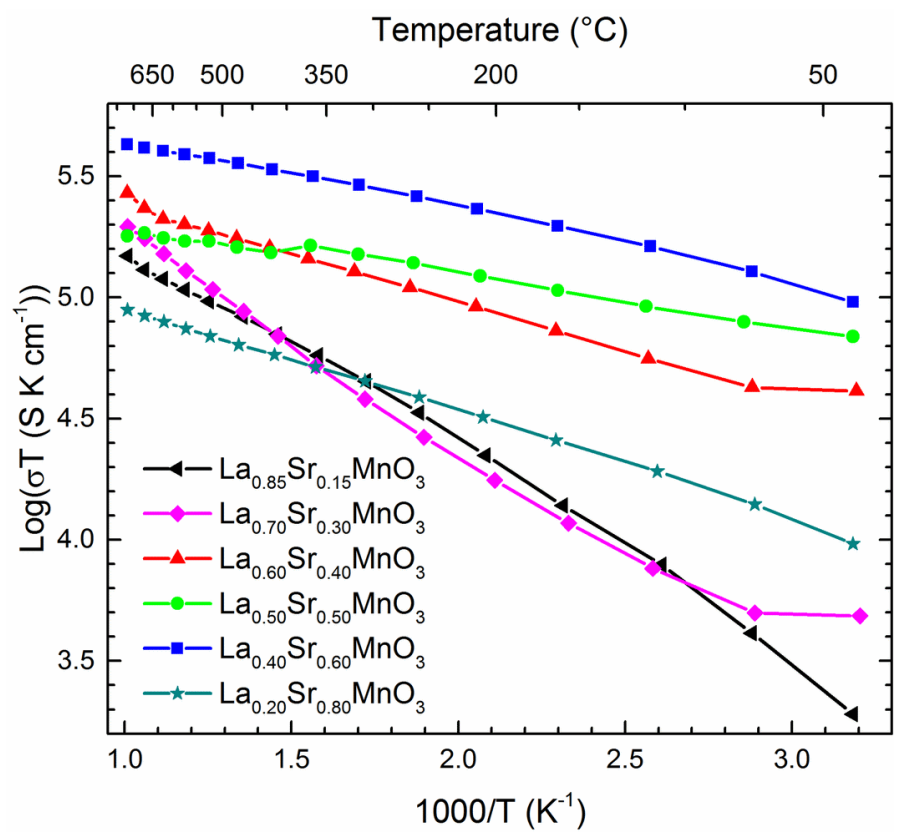

Figure 3: Electrical conductivities as a function of the temperature measured under air for all the LSMS compositions studied

Table 1: Structural and physical parameters of the materials used in this study.

\begin{tabular}{|c|c|c|c|c|c|c|c|c|}
\hline Composition & $\delta$ & $\begin{array}{l}\text { Space } \\
\text { Group }\end{array}$ & $\mathrm{a}(\AA)$ & $\mathrm{b}(\AA)$ & $\mathrm{c}(\AA)$ & $\begin{array}{c}\text { TECX } 10^{6} \\
\left(\mathrm{~K}^{-1}\right)\end{array}$ & $\begin{array}{c}\sigma @, 500{ }^{\circ} \mathrm{C} \\
\left(\mathrm{S} \mathrm{cm}^{-1}\right)\end{array}$ & $\begin{array}{c}\text { Average Mn } \\
\text { oxidation state }\end{array}$ \\
\hline & & & & & $13.3694(2$ & & & \\
\hline $\mathrm{La}_{0.85} \mathrm{Sr}_{0.15} \mathrm{MnO}_{3+\delta}$ & 0.09 & $R \overline{3} c$ & \multicolumn{2}{|c|}{$5.53551(5)$} & ) & 14.9 & 117 & 3.3 \\
\hline $\mathrm{La}_{0.7} \mathrm{Sr}_{0.3} \mathrm{MnO}_{3+\delta}$ & 0.02 & $R \overline{3} c$ & \multicolumn{2}{|c|}{$5.5092(5)$} & $13.371(1)$ & 12.8 & 131 & 3.3 \\
\hline $\mathrm{La}_{0.6} \mathrm{Sr}_{0.4} \mathrm{MnO}_{3+\delta}$ & 0.03 & $R \overline{3} c$ & \multicolumn{2}{|c|}{$5.4912(4)$} & $13.361(1)$ & 13.3 & 235 & 3.5 \\
\hline $\mathrm{La}_{0.5} \mathrm{Sr}_{0.5} \mathrm{MnO}_{3+\delta}$ & $<0.01$ & Pnma & $5.4650(3)$ & $7.6917(4)$ & $5.4825(3)$ & 14.1 & 215 & 3.5 \\
\hline $\mathrm{La}_{0.4} \mathrm{Sr}_{0.6} \mathrm{MnO}_{3+\delta}$ & $<0.01$ & Pnma & $5.467(2)$ & $7.6732(1)$ & $5.471(2)$ & 13.6 & 474 & 3.6 \\
\hline $\mathrm{La}_{0.2} \mathrm{Sr}_{0.8} \mathrm{MnO}_{3+\delta}$ & $<0.01$ & Pnma & $5.4561(1)$ & $7.6369(1)$ & $5.4327(1)$ & 14.5 & 86 & 3.8 \\
\hline $\mathrm{Bi}_{1.5} \mathrm{Er}_{0.5} \mathrm{O}_{3}$ & - & $P m \overline{3} m$ & & $5.4852(1)$ & & 16.5 & $2.02 \times 10^{-2}$ & - \\
\hline
\end{tabular}

\subsection{Electrode performance}


The chemical stability of the ESB/LSM interface was investigated by mixing $\mathrm{Bi}_{1.5} \mathrm{Er}_{0.5} \mathrm{O}_{3}$ and $\mathrm{La}_{0.85} \mathrm{Sr}_{0.15} \mathrm{MnO}_{3}$ and annealing the mixture at $800{ }^{\circ} \mathrm{C}$ for $24 \mathrm{~h}$. No impurity is visible on the resulting diffraction pattern (Fig. 4-a) demonstrating the excellent chemical compatibility of these two oxides up to at least $800{ }^{\circ} \mathrm{C}$. This combination of materials was used to study the optimal electrode thickness, grafting temperature and ESB/LSM ratio. The optimized parameters were selected based on the data presented in Figure S3, resulting in symmetric cells with an electrode thickness of $\sim 50-60 \mu \mathrm{m}$, composed of a ESB/LSM 50/50 wt.\% ratio, grafted at $800{ }^{\circ} \mathrm{C}$. Post mortem imaging of the cross-section of the symmetric cells (Fig. 4-b) after impedance spectroscopy shows micron sized ESB particles well dispersed in a framework of slightly larger LSM grains. The electrode/electrolyte interface did not show any sign of delamination and no crack could be seen on the electrode despite the three thermal cycles from room temperature to $800{ }^{\circ} \mathrm{C}$ the symmetric cell was subjected to, showing promising mechanical compatibility. The stability of these electrodes is also reflected by the stability of their electrochemical impedance spectra during these three thermal cycles, at both ends of the temperature range considered (Fig. S4), supporting the absence of secondary phases growth.
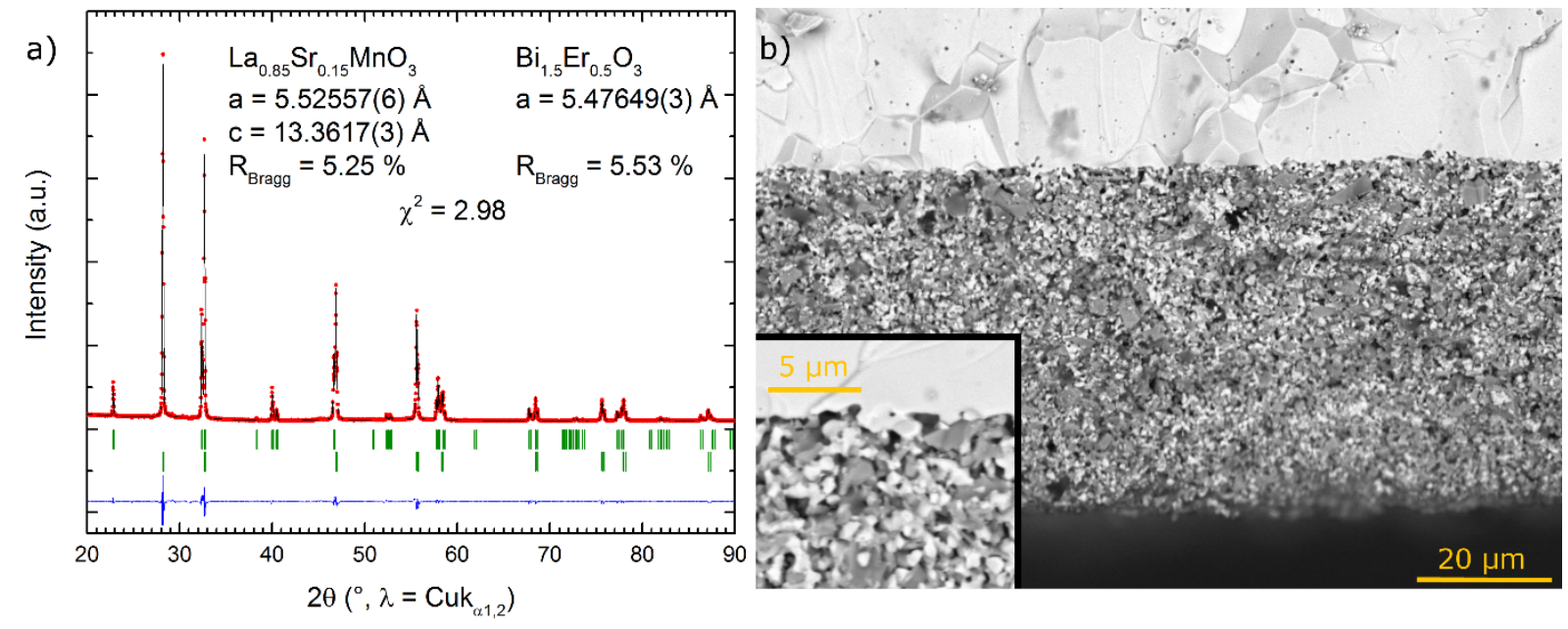

Figure 4: a) Rietveld refinement showing data points (red dots), calculated profile (black line) difference curve (blue line) and Bragg peak position of a mixture of $\mathrm{La}_{0.85} \mathrm{Sr}_{0.15} \mathrm{MnO}_{3}$ (upper green bars) and $\mathrm{Bi}_{1.5} \mathrm{Er}_{0.5} \mathrm{O}_{3}$ (lower 
green bars) annealed at $800{ }^{\circ} \mathrm{C}$ for 24 h. b) Post-analysis SEM images obtained in back-scattered electron mode of the cross section of a symmetric cell showing part of the ESB electrolyte and one ESB/LSM electrode. Due to the Z-contrast, particles of ESB appear brighter than LSM ones.

Careful inspection of the electrochemical impedance spectrum of $\mathrm{La}_{0.85} \mathrm{Sr}_{0.15} \mathrm{MnO}_{3} / \mathrm{ESB}$ symmetric cells at $678{ }^{\circ} \mathrm{C}$ reveals the presence of at least three components (Fig. 5-a, upper pane). Each phenomenon was modeled using a constant phase element in parallel with a resistive element in order to extract their temperature dependence (Fig. 5-b). In agreement with previously published results on similar compositions, ${ }^{23,29}$ we obtained two thermally activated phenomena with different activation energy and frequency range. One temperature independent phenomena was also observed at low frequencies which is the typical signature of gaseous $\mathrm{O}_{2}$ diffusion limitation. Since this contribution is strongly related to the instrumentation, due to the large gold current collectors and static atmosphere used in this study, it was not accounted in the actual ASR of the electrodes thereafter. ${ }^{41}$ This contribution was fitted at high temperature, where it is easily modeled, and fixed at lower temperature, where it has negligible contribution to the overall ASR. The activation energy for the gas diffusion process at high temperature was in the order of $0.05 \mathrm{eV}$ based on the few high temperature points where this contribution was easily refined. 
a)

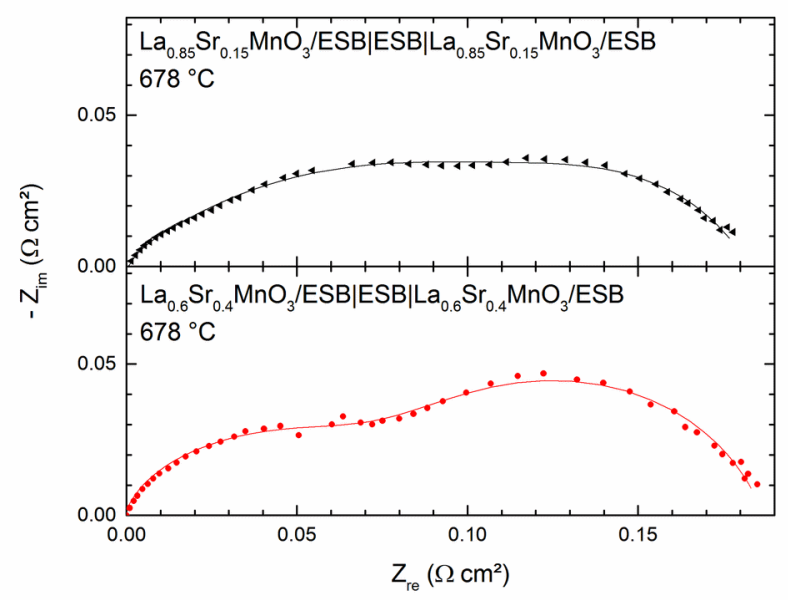

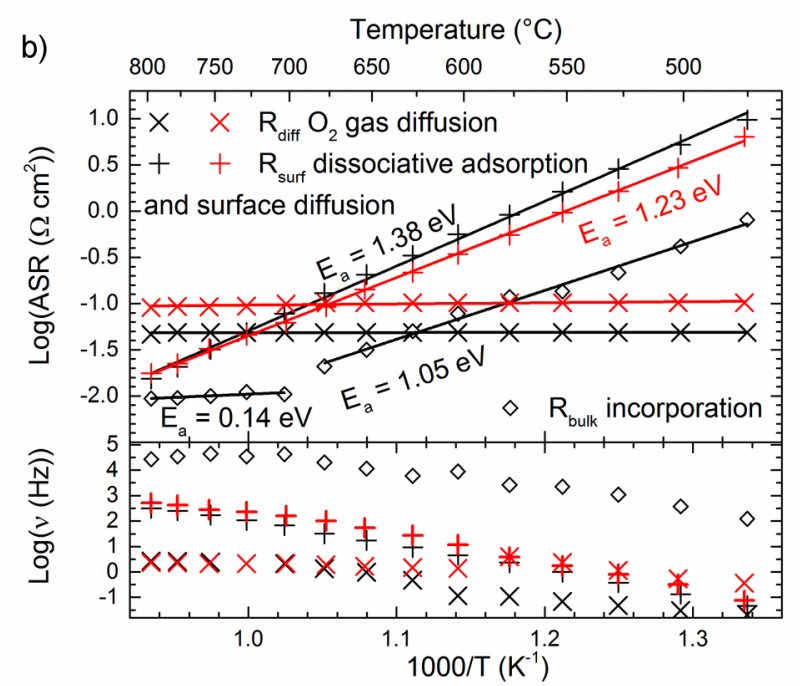

Figure 5: a) EIS spectra of the electrode response of the $\mathrm{La}_{1-x} \mathrm{Sr}_{x} \mathrm{MnO} \mathrm{O}_{3} / \mathrm{ESB}|\mathrm{ESB}| \mathrm{La}_{1_{-x}} \mathrm{Sr}_{x} \mathrm{MnO} \mathrm{O}_{3} / \mathrm{ESB}$ symmetric cells at $678^{\circ} \mathrm{C}$ for $x=0.15$ (upper pane) and $x=0.4$ (lower pane); the continuous lines represent the spectrum calculated from the fit. b) Temperature dependence of the resistance (upper pane) and characteristic frequencies of the different phenomena observed for $x=0.15$ (black) and $x=0.4$ (red).

The two thermally activated processes showed very similar behavior with previously published results on $\mathrm{La}_{0.2} \mathrm{Sr}_{0.8} \mathrm{MnO}_{3} / \mathrm{Bi}_{0.6} \mathrm{Er}_{0.4} \mathrm{O}_{3}$ composite electrodes. ${ }^{23,29}$ The lower frequency phenomenon was clearly the limiting step with an associated resistance about one order of magnitude larger than the higher frequency phenomenon. In our study as well, the high frequency element showed an increase of its activation energy as the temperature was lowered below $700{ }^{\circ} \mathrm{C}$. Based on the very different frequency range, the limiting process with an activation energy of $1.38 \mathrm{eV}$ was ascribed to the dissociative adsorption of oxygen on the surface of LSM and the subsequent surface migration of the ionic species generated. The second phenomenon, at high frequency, exhibiting a break in its activation energy at temperatures similar to the change of slope observed in the conductivity of ESB (Fig. S1-b) was assigned to bulk incorporation of oxo anions into ESB..$^{23,29}$

Differently from $\mathrm{La}_{0.85} \mathrm{Sr}_{0.15} \mathrm{MnO}_{3}$, the high frequency bulk diffusion process was not observed for LSM compositions with $\mathrm{x}>0.15$, as exemplified here with $\mathrm{La}_{0.6} \mathrm{Sr}_{0.4} \mathrm{MnO}_{3}$ (Fig. 
5, red curves). The magnitude and the frequency range of the remaining constant phase element clearly show that the modeled phenomenon can be unambiguously attributed to the surface properties of the electrode. The ASR, corrected for gaseous diffusion, of all the composite electrodes under study are reported in Figure 6. Except for $\mathrm{La}_{0.2} \mathrm{Sr}_{0.8} \mathrm{MnO}_{3}$, all the compositions display fairly similar performance. At low temperature the two compositions $\mathrm{La}_{0.6} \mathrm{Sr}_{0.4} \mathrm{MnO}_{3}$ and $\mathrm{La}_{0.5} \mathrm{Sr}_{0.5} \mathrm{MnO}_{3}$ clearly stand out, mostly due to their lower activation energy. Interestingly, the increase in strontium concentration from $\mathrm{x}=0.15$ to $\mathrm{x}=0.4$ induces a $\sim 14 \%$ decrease in the energy required to dissociate the oxygen molecules and/or transfer the oxygen ions on the surface of the electrode. Lower activation energy is a key parameter to control when considering the reduction of the operating temperature. It resulted in our case in a polarization resistance at $500{ }^{\circ} \mathrm{C}$ almost twice as small for $\mathrm{x}=0.4$ than for $\mathrm{x}=0.15$ (see inset, Fig 6). Further increase in the strontium content, corresponding to composition containing a small amount of $4 \mathrm{H}-$ hexagonal perovskite as impurity, showed a rapid increase of both the polarization resistance and the activation energy. However, it is worth noting that the large decrease in the ASR of the $\mathrm{La}_{0.2} \mathrm{Sr}_{0.8} \mathrm{MnO}_{3}$ for temperature higher than $750{ }^{\circ} \mathrm{C}$ was reversible and observed in all three thermal cycles the symmetric cell was subjected to (Fig. S5-a). High temperature diffraction failed to evidence any structural event at this temperature (Fig. S5-b) that could explain this anomaly. In particular, the proportion of $4 \mathrm{H}-$ hexagonal perovskite remained identical, confirming our initial assumption that this impurity has only marginal role in the overall performance of $\mathrm{La}_{0.2} \mathrm{Sr}_{0.8} \mathrm{MnO}_{3}$. 


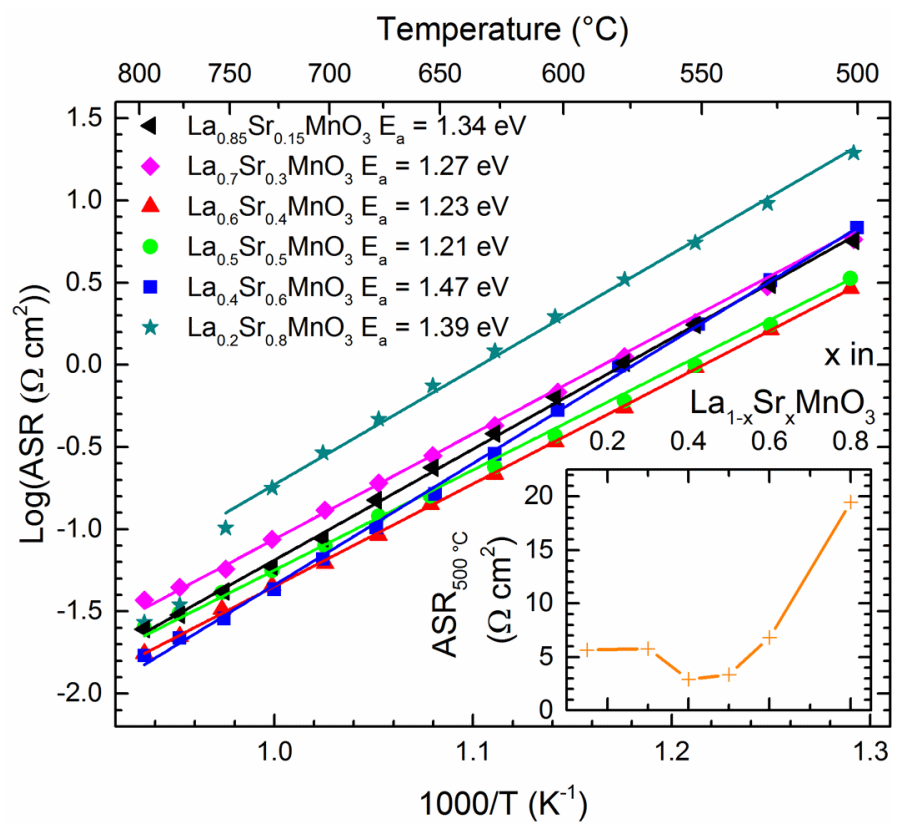

Figure 6: Temperature dependence of the ASR (corrected for gaseous diffusion) of $\mathrm{La}_{1-x} \mathrm{Sr}_{x} \mathrm{MnO}_{3} / \mathrm{ESB}$ symmetric cells for $x=0.15,0.3,0.4,0.5,0.6,0.8$. Lower left inset represents the evolution of the ASR as a function of the chemical composition at a fixed temperature of $500^{\circ} \mathrm{C}$.

\subsection{Discussion}

The performance of $\mathrm{La}_{1-\mathrm{x}} \mathrm{Sr}_{\mathrm{x}} \mathrm{MnO}_{3} / \mathrm{ESB}$ composite electrodes cannot be simply linked to the electronic conductivity of the LSM as evidenced by the fact that $\mathrm{La}_{0.4} \mathrm{Sr}_{0.6} \mathrm{MnO}_{3}$, the best electronic conductor of the series, is one of the lower performance material at reduced temperature. It is clear that the decrease in the polarization resistance observed for $\mathrm{x}=0.4-$ 0.5 at low temperature is related to the lower activation energy of the surface processes involved during the catalytic dissociation of the $\mathrm{O}_{2}$ molecules. This is in good agreement with studies on oxygen transfer by isotope exchange. Using tracer diffusion profile, the oxygen surface exchange coefficient of $\mathrm{La}_{0.80} \mathrm{Sr}_{0.2} \mathrm{MnO}_{3}{ }^{42} \mathrm{La}_{0.65} \mathrm{Sr}_{0.55} \mathrm{MnO}_{3}$ and $\mathrm{La}_{0.5} \mathrm{Sr}_{0.5} \mathrm{MnO}_{3}{ }^{43}$ were measured at $900{ }^{\circ} \mathrm{C}$ to be $\mathrm{k}^{*}=8 \times 10^{-9}, 5 \times 10^{-8}$ and $9 \times 10^{-8} \mathrm{~cm} \mathrm{~s}^{-1}$ respectively, showing that the efficiency of the oxygen dissociation increases with the Sr-content in these perovskites. However, the segregation of $\mathrm{SrO}$ on the surface of perovskite materials is generally thought as the main limiting factor of perovskite materials. ${ }^{44-46}$ The migration of strontium species on the 
surface of $\mathrm{La}_{0.6} \mathrm{Sr}_{0.4} \mathrm{Co}_{0.2} \mathrm{Fe}_{0.8} \mathrm{O}_{3-\delta}$ (LSCF) was evidenced by Low-Energy Ion Scattering (LEIS), the driving force being the formation of a neutral $\mathrm{Sr}^{2+}-\mathrm{O}^{2-}$ surface layer while other cations, being trivalent, would result in a polar surface. ${ }^{44} \mathrm{~A}$ similar mechanism was expected for LSM based on reports of the surface enrichment in $\mathrm{Sr}^{2+}$ measured by XPS. ${ }^{46-49}$ Hence the enhanced catalytic properties that we observe by increasing the strontium content up to 0.4 0.5 in $\mathrm{La}_{1-\mathrm{x}} \mathrm{Sr}_{\mathrm{x}} \mathrm{MnO}_{3}$ is unexpected. Despite the significance of LSM electrodes, we could not find published LEIS spectra, the only technique able to selectively probe the top atomic layer, other than a brief confirmation of Sr-surface segregation presented at a conference. ${ }^{50}$
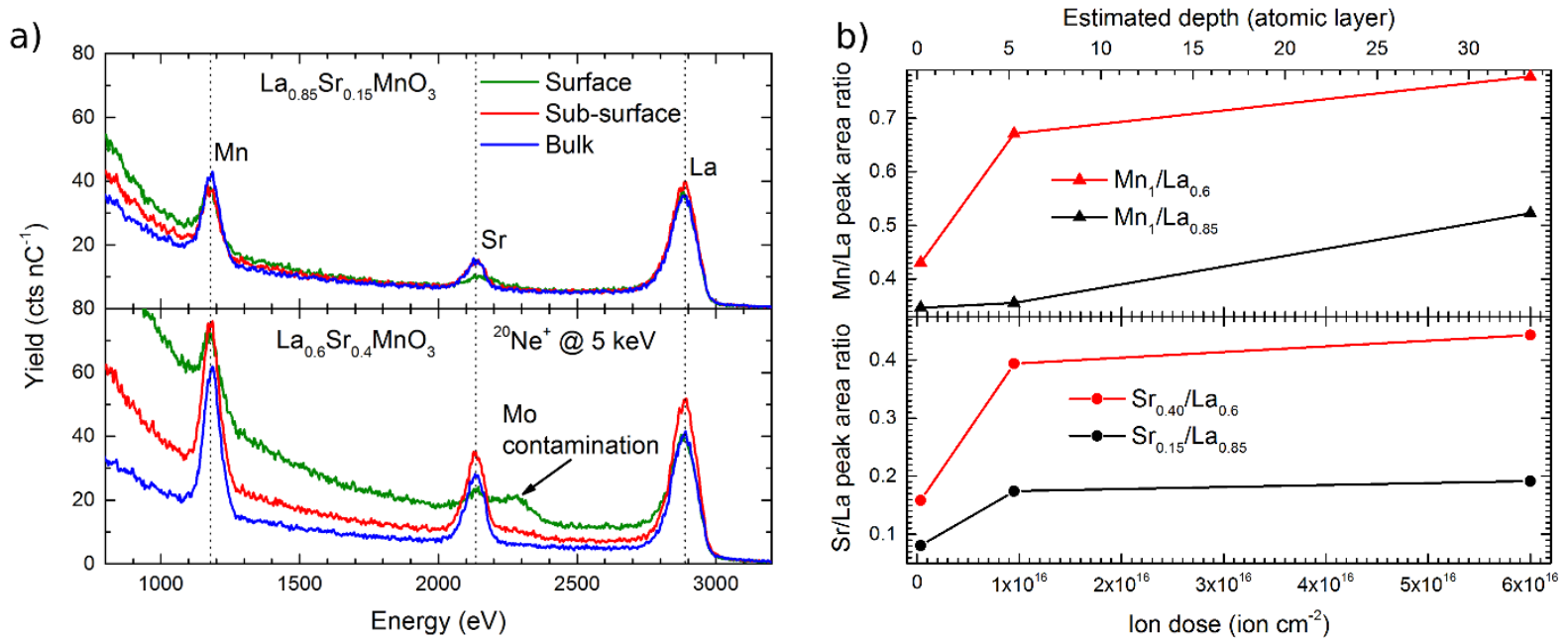

Figure 7: a) ${ }^{20} \mathrm{Ne}^{+} @ 5 \mathrm{keV}$ LEIS spectra of $\mathrm{La}_{0.85} \mathrm{Sr}_{0.15} \mathrm{MnO}_{3}$ (upper pane) and $\mathrm{La}_{0.6} \mathrm{Sr}_{0.4} \mathrm{MnO}_{3}$ (lower pane) at three different ion doses corresponding to compositions at the surface (green), the sub-surface (red) and the bulk (blue) of the materials and b) evolution of the peak area of strontium (dots) and manganese (triangle) relative to the peak area of lanthanum as a function of the depth for $\mathrm{La}_{0.85} \mathrm{Sr}_{0.15} \mathrm{MnO}_{3}$ (black) and $\mathrm{La}_{0.6} \mathrm{La}_{0.4} \mathrm{MnO}_{3}$ (red).

We therefore used LEIS to look at the surface composition of $\mathrm{La}_{0.85} \mathrm{Sr}_{0.15} \mathrm{MnO}_{3}$ and $\mathrm{La}_{0.6} \mathrm{Sr}_{0.4} \mathrm{MnO}_{3}$ after a $72 \mathrm{~h}$ annealing at $800{ }^{\circ} \mathrm{C}$ in air, i.e. the temperature and atmosphere used for symmetric cells preparation. As shown in Figure 7, in contrast to previous assumptions, all three cations are present on the outermost surface in these conditions. Additionally a small molybdenum contamination, probably due to the evaporation of the 
$\mathrm{MoSi}_{2}$ heating elements, is visible, on the surface only, for $\mathrm{x}=0.4$. However, by looking at the evolution of the composition as a function of the depth, it is clear that the surface of these oxides is actually Sr-deficient.

While this is surprising considering the HT-SOFC literature, it was previously reported that low-temperature annealing of LSM resulted in the suppression of the strontium segregation, ${ }^{49}$ in good agreement with the performance and stability of LSM/ESB LT-SOFC electrodes. As shown in Figure 7-b, for both materials the $\mathrm{Sr} / \mathrm{La}$ ratio stabilizes rapidly after removal of the first few atomic layers. In contrast, the evolution of the $\mathrm{Mn} / \mathrm{La}$ ratio shows very different behavior. In the case of $\mathrm{La}_{0.85} \mathrm{Sr}_{0.15} \mathrm{MnO}_{3}$, the concentration of manganese species increases slowly with the depth, consequently the subsurface $\mathrm{Mn} / \mathrm{La}$ ratio is almost equal to the surface level and a $50 \%$ increase is observed once the bulk of the material is being analyzed. Conversely, $\mathrm{La}_{0.6} \mathrm{Sr}_{0.4} \mathrm{MnO}_{3}$ exhibits a rapid increase of the $\mathrm{Mn} / \mathrm{La}$ from the surface to the sub-surface level and only a $15 \%$ increase once the bulk of the material is reached. This indicates a deficiency in manganese at the surface, compared to the bulk for both compositions but the deficiency impacts a much larger volume for the La rich composition.

In order to understand the evolution of the cationic ratios it is important to remember that $\mathrm{La}_{1-\mathrm{x}} \mathrm{Sr}_{\mathrm{x}} \mathrm{MnO}_{3}$ perovskites with high $\mathrm{Mn}^{3+}$ content, i.e. lanthanum rich compositions, spontaneously oxidize on cooling, resulting in the formation of cationic vacancies rather than the insertion of interstitial oxygen. Because oxygen does not diffuse in LSM, this oxidation process implies that the outer surface of the grain gradually grows by capturing oxygen and stabilizing it into the structure thanks to the migration of cations from the bulk (Fig. S6). Our LEIS results indicate that the concentration of Mn-vacancies are significantly higher on the surface of the materials compare to the bulk while the A-site vacancies are much more homogeneously distributed throughout the materials. This distribution of the cationic 
vacancies is most probably related to difference in mobility between the A-site and B-site cations. While the former have a straightforward diffusion path through an $\mathrm{O}_{4}$ square window, B-site cations have to hop from one octahedral site to the next going through two triangular $\mathrm{O}_{3}$ windows. Because of its higher oxygen overstoichiometry, $\mathrm{La}_{0.85} \mathrm{Sr}_{0.15} \mathrm{MnO}_{3+\delta}(\delta=0.09)$, exhibits a high concentration of Mn-vacancies reaching at least a couple of atomic layers deep. On the other hand, $\mathrm{La}_{0.6} \mathrm{Sr}_{0.4} \mathrm{MnO}_{3+\delta}(\delta=0.03)$, needs to accommodate a reduced number of vacancies, restricting the vacancies to the outermost surface. Hence, mitigating the cationic vacancies using a higher Sr-content enables a higher Mn-content on the outermost surface and sub-surface, critical for oxygen dissociation and surface transport.

Finally, it is interesting to note that the high-frequency ionic contribution to the ASR of $\mathrm{La}_{0.85} \mathrm{Sr}_{0.15} \mathrm{MnO}_{3} / \mathrm{ESB}$ composite electrode is suppressed by even small amount of $\mathrm{Sr}^{2+}$. This contribution sets the $\mathrm{x}=0.15$ composition clearly aside from all the other, also pointing at the detrimental role of cationic vacancies.

\section{Conclusion}

We showed in this work that it is possible to increase the already promising performance of LSM/ESB composite electrodes through the optimization of the strontium content in $\mathrm{La}_{1-\mathrm{x}} \mathrm{Sr}_{\mathrm{x}} \mathrm{MnO}_{3}$. By using composition with $\mathrm{x}=0.4-0.5$, rather than the typical high temperature oxides with $\mathrm{x}=0.15-0.2$, it is possible to accelerate both the oxygen surface and bulk diffusion phenomena taking place in the electrodes. In particular the significant decrease of the activation energy of the oxygen dissociation and surface migration offers a decrease of the ASR by approximatively $50 \%$ at reduced temperature.

The limiting steps of the oxygen reduction reaction are confirmed to be located on the surface of the ESB/LSM electrodes and therefore the surface composition of the $\mathrm{La}_{1-\mathrm{x}} \mathrm{Sr}_{\mathrm{x}} \mathrm{MnO}_{3}$ 
material is expected to play a major role in the overall catalytic activity. We showed using LEIS that the important non-stoichiometry observed for $\mathrm{La}_{0.85} \mathrm{Sr}_{0.15} \mathrm{MnO}_{3+\delta}(\delta \sim 0.09)$ composition results in a high concentration of manganese vacancies on the surface and subsurface level. For this reason, Sr-rich compositions which are near-stoichiometric exhibit higher Mn concentration at the outermost surface which is likely the reason for the increased catalytic activity of $\mathrm{La}_{1-\mathrm{x}} \mathrm{Sr}_{\mathrm{x}} \mathrm{MnO}_{3}$ with $\mathrm{x}=0.4$ and 0.5 . Contrary to what is expected from high temperature literature, we do not observe SrO segregation at the surface of LSM below $800{ }^{\circ} \mathrm{C}$, even in the case of $\mathrm{La}_{0.6} \mathrm{Sr}_{0.4} \mathrm{MnO}_{3}$ which is a good sign of the stability of the electrode. Further increase in the strontium content, i.e. for $\mathrm{x}=0.6-0.8$, results in the formation of $4 \mathrm{H}-$ hexagonal perovskite and a rapid decay of the electrochemical performance. It is not clear whether the impurity directly impedes the ORR or if it is a consequence of the change in the surface chemistry of the LSM particles. Results obtained by LEIS are preliminary, a more detailed study of the surface composition of the various strontium doped manganites will be undertaken to refine our understanding of the oxygen reduction reaction mechanism at reduced temperature. However, our work clearly highlights that the development of lower temperature SOFCs must take into account the flexibility offered by the reduced temperature range and the need to reinvestigate materials that were set aside for higher temperature applications due to their chemical or mechanical incompatibilities.

\section{Acknowledgements}

This work is supported by the French National Research Agency (ANR-18-CE05-0001) as well as the Region Haut de France. The Chevreul Institute (FR 2638), ULille, the Fonds Européen de Développement Régional (FEDER), CNRS, are acknowledged for the access to the various characterisation platforms. MP is grateful to ULille and Region Haut de France for 
his $\mathrm{PhD}$ grant. Special thanks to Romain Jooris for his help with measurement and data handling.

\section{Bibliography}

(1) Ellamla, H. R.; Staffell, I.; Bujlo, P.; Pollet, B. G.; Pasupathi, S. Current Status of Fuel Cell Based Combined Heat and Power Systems for Residential Sector. J. Power Sources 2015, 293, 312-328. https://doi.org/10.1016/j.jpowsour.2015.05.050.

(2) Gao, Z.; Mogni, L. V.; Miller, E. C.; Railsback, J. G.; Barnett, S. A. A Perspective on Low-Temperature Solid Oxide Fuel Cells. Energy Environ. Sci. 2016, 9 (5), 1602-1644. https://doi.org/10.1039/C5EE03858H.

(3) Wachsman, E. D; Lee, K. T. Lowering the Temperature of Solid Oxide Fuel Cells. Science 2011, 334 (6058), 935-939. https://doi.org/10.1126/science.1204090.

(4) Shao, Z.; Haile, S. M. A High-Performance Cathode for the next Generation of SolidOxide Fuel Cells. Nature 2004, 431 (7005), 170. https://doi.org/10.1038/nature02863.

(5) Ahn, J. S.; Pergolesi, D.; Camaratta, M. A.; Yoon, H.; Lee, B. W.; Lee, K. T.; Jung, D. W.; Traversa, E.; Wachsman, E. D. High-Performance Bilayered Electrolyte Intermediate Temperature Solid Oxide Fuel Cells. Electrochem. Commun. 2009, 11 (7), 1504-1507. https://doi.org/10.1016/j.elecom.2009.05.041.

(6) Skinner, S. J. Recent Advances in Perovskite-Type Materials for Solid Oxide Fuel Cell Cathodes. Int. J. Inorg. Mater. 2001, 3 (2), 113-121. https://doi.org/10.1016/S14666049(01)00004-6.

(7) Jiang, S. P. Development of Lanthanum Strontium Manganite Perovskite Cathode Materials of Solid Oxide Fuel Cells: A Review. J. Mater. Sci. 2008, 43 (21), 6799-6833. https://doi.org/10.1007/s10853-008-2966-6.

(8) Tsipis, E. V.; Kharton, V. V. Electrode Materials and Reaction Mechanisms in Solid Oxide Fuel Cells: A Brief Review. J. Solid State Electrochem. 2008, 12 (11), 13671391. https://doi.org/10.1007/s10008-008-0611-6.

(9) Heuveln, F. H. van; Bouwmeester, H. J. M. Electrode Properties of Sr-Doped LaMnO3 on Yttria-Stabilized Zirconia II. Electrode Kinetics. J. Electrochem. Soc. 1997, 144 (1), 134-140. https://doi.org/10.1149/1.1837375.

(10) Kim, J.-D.; Kim, G.-D.; Moon, J.-W.; Park, Y.; Lee, W.-H.; Kobayashi, K.; Nagai, M.; Kim, C.-E. Characterization of LSM-YSZ Composite Electrode by Ac Impedance Spectroscopy. Solid State Ion. 2001, 143 (3), 379-389. https://doi.org/10.1016/S01672738(01)00877-3.

(11) Lee, H.-K. Electrochemical Characteristics of La1-xSrxMnO3 for Solid Oxide Fuel Cell. Mater. Chem. Phys. 2003, 77 (3), 639-646. https://doi.org/10.1016/S02540584(02)00091-3.

(12) Mizusaki, J.; Yonemura, Y.; Kamata, H.; Ohyama, K.; Mori, N.; Takai, H.; Tagawa, H.; Dokiya, M.; Naraya, K.; Sasamoto, T.; et al. Electronic Conductivity, Seebeck Coefficient, Defect and Electronic Structure of Nonstoichiometric La1-xSrxMnO3. Solid State Ion. 2000, 132 (3), 167-180. https://doi.org/10.1016/S0167-2738(00)006627.

(13) Sakaki, Y.; Takeda, Y.; Kato, A.; Imanishi, N.; Yamamoto, O.; Hattori, M.; Esaki, Y. Ln1-XSrxMnO3(Ln=Pr, Nd, Sm and Gd) as the Cathode Material for Solid Oxide Fuel Cells. J. Jpn. Soc. Powder Powder Metall. 1999, 46 (3), 293-299. https://doi.org/10.2497/jjspm.46.293. 
(14) Hammouche, A.; Siebert, E.; Hammou, A. Crystallographic, Thermal and Electrochemical Properties of the System La1-xSrxMnO3 for High Temperature Solid Electrolyte Fuel Cells. Mater. Res. Bull. 1989, 24 (3), 367-380. https://doi.org/10.1016/0025-5408(89)90223-7.

(15) Yokokawa, H.; Horita, T.; Sakai, N.; Dokiya, M.; Kawada, T. Thermodynamic Representation of Nonstoichiometric Lanthanum Manganite. Solid State Ion. 1996, 8688, 1161-1165. https://doi.org/10.1016/0167-2738(96)00281-0.

(16) Jiang, S. P.; Zhang, J. P.; Ramprakash, Y.; Milosevic, D.; Wilshier, K. An Investigation of Shelf-Life of Strontium Doped LaMnO3 Materials. J. Mater. Sci. 2000, 35 (11), 2735-2741. https://doi.org/10.1023/A:1004766212164.

(17) Jiang, Z.; Zhang, L.; Feng, K.; Xia, C. Nanoscale Bismuth Oxide Impregnated (La,Sr)MnO3 Cathodes for Intermediate-Temperature Solid Oxide Fuel Cells. J. Power Sources 2008, 185 (1), 40-48. https://doi.org/10.1016/j.jpowsour.2008.07.003.

(18) Li, J.; Wang, S.; Wang, Z.; Liu, R.; Wen, T.; Wen, Z. (La0.74Bi0.10Sr0.16)MnO3- (Bi2O3)0.7(Er2O3)0.3 Composite Cathodes for Intermediate Temperature Solid Oxide Fuel Cells. J. Power Sources 2008, 179 (2), 474-480. https://doi.org/10.1016/j.jpowsour.2008.01.017.

(19) Jiang, Z.; Xia, C.; Zhao, F.; Chen, F. La0.85Sr0.15MnO3 - $\delta$ Infiltrated Y0.5Bi1.5O3 Cathodes for Intermediate-Temperature Solid Oxide Fuel Cells. Electrochem. SolidState Lett. 2009, 12 (6), B91-B93. https://doi.org/10.1149/1.3099321.

(20) Jiang, Z.; Zhang, L.; Cai, L.; Xia, C. Bismuth Oxide-Coated (La,Sr)MnO3 Cathodes for Intermediate Temperature Solid Oxide Fuel Cells with Yttria-Stabilized Zirconia Electrolytes. Electrochimica Acta 2009, 54 (11), 3059-3065. https://doi.org/10.1016/j.electacta.2008.11.067.

(21) Li, J.; Wang, S.; Wang, Z.; Liu, R.; Wen, T.; Wen, Z. La0.84Sr0.16MnO3- $\delta$ Cathodes Impregnated with Bi1.4Er0.6O3 for Intermediate-Temperature Solid Oxide Fuel Cells. $J$. Power Sources 2009, 194 (2), 625-630. https://doi.org/10.1016/j.jpowsour.2009.06.070.

(22) Jiang, Z.; Lei, Z.; Ding, B.; Xia, C.; Zhao, F.; Chen, F. Electrochemical Characteristics of Solid Oxide Fuel Cell Cathodes Prepared by Infiltrating (La,Sr)MnO3 Nanoparticles into Yttria-Stabilized Bismuth Oxide Backbones. Int. J. Hydrog. Energy 2010, 35 (15), 8322-8330. https://doi.org/10.1016/j.ijhydene.2009.12.008.

(23) Lee, K. T.; Jung, D. W.; Yoon, H. S.; Lidie, A. A.; Camaratta, M. A.; Wachsman, E. D. Interfacial Modification of $\mathrm{La} 0.80 \mathrm{Sr} 0.20 \mathrm{MnO} 3-\delta-E r 0.4 \mathrm{Bi} 0.6 \mathrm{O} 3$ Cathodes for High Performance Lower Temperature Solid Oxide Fuel Cells. J. Power Sources 2012, 220, 324-330. https://doi.org/10.1016/j.jpowsour.2012.08.004.

(24) Ai, N.; Li, N.; He, S.; Cheng, Y.; Saunders, M.; Chen, K.; Zhang, T.; Ping Jiang, S. Highly Active and Stable Er0.4Bi1.6O3 Decorated La0.76Sr0.19MnO3 $+\delta$ Nanostructured Oxygen Electrodes for Reversible Solid Oxide Cells. J. Mater. Chem. A 2017, 5 (24), 12149-12157. https://doi.org/10.1039/C7TA02950K.

(25) Huang, Y.-L.; Pellegrinelli, C.; Painter, A. S.; Wachsman, E. D. Electrochemical Performance and Stability of LSM-ESB Cathode. ECS Trans. 2017, 78 (1), 573-580. https://doi.org/10.1149/07801.0573ecst.

(26) Kim, S. J.; Dayaghi, A. M.; Kim, K. J.; Choi, G. M. Er0.4Bi1.6O3- $\delta$ La0.8Sr0.2MnO3 $-\delta$ Nano-Composite as a Low-Temperature Firing Cathode of Solid Oxide Fuel Cell. J. Power Sources 2017, 344, 218-222. https://doi.org/10.1016/j.jpowsour.2017.01.110.

(27) Painter, A. S.; Huang, Y.-L.; Wachsman, E. D. Durability of (La0.8Sr0.2)0.95MnO3- $\delta$ (Er0.2Bi0.8)2O3 Composite Cathodes for Low Temperature SOFCs. J. Power Sources 2017, 360, 391-398. https://doi.org/10.1016/j.jpowsour.2017.06.018. 
(28) Park, J. W.; Joh, D. W.; Yun, B.-H.; Samdani, K. J.; Lee, K. T. Development of Nanostructured $\mathrm{La} 0.8 \mathrm{Sr} 0.2 \mathrm{MnO} 3-\delta$-Er0.4Bi1.6O3 Cathodes via an Infiltration Process with Different Polymeric Agents for Intermediate Temperature Solid Oxide Fuel Cells. Int. J. Hydrog. Energy 2017, $42 \quad$ (9), 6332-6337. https://doi.org/10.1016/j.ijhydene.2016.11.175.

(29) Park, J. W.; Lee, K. T. Enhancing Performance of La0.8Sr0.2MnO3- $\delta$-Infiltrated Er0.4Bi1.6O3 Cathodes via Controlling Wettability and Catalyst Loading of the Precursor Solution for IT-SOFCs. J. Ind. Eng. Chem. 2018, 60, 505-512. https://doi.org/10.1016/j.jiec.2017.11.039.

(30) Iwahara, H.; Esaka, T.; Sato, T.; Takahashi, T. Formation of High Oxide Ion Conductive Phases in the Sintered Oxides of the System Bi2O3-Ln2O3 $(\mathrm{Ln}=\mathrm{La}-\mathrm{Yb})$. J. Solid State Chem. 1981, 39 (2), 173-180. https://doi.org/10.1016/0022-4596(81)90328-5.

(31) Kruidhof, H.; Seshan, K.; van de Velde, G. M. H.; de Vries, K. J.; Burggraaf, A. J. Bismuth Oxide Based Ceramics with Improved Electrical and Mechanical Properties: Part II. Structural and Mechanical Properties. Mater. Res. Bull. 1988, 23 (3), 371-377. https://doi.org/10.1016/0025-5408(88)90011-6.

(32) Kruidhof, H.; Seshan, K.; Lippens, B. C.; Gellings, P. J.; Burggraaf, A. J. Bismuth Oxide Based Ceramics with Improved Electrical and Mechanical Properties: Part I. Preparation and Characterisation. Mater. Res. Bull. 1987, 22 (12), 1635-1643. https://doi.org/10.1016/0025-5408(87)90006-7.

(33) Rolle, A.; Mohamed, H. A. A.; Huo, D.; Capoen, E.; Mentré, O.; Vannier, R.-N.; Daviero-Minaud, S.; Boukamp, B. A. Ca3Co4O9+ $\delta$, a Growing Potential SOFC Cathode Material: Impact of the Layer Composition and Thickness on the Electrochemical Properties. Solid State Ion. 2016, 294, 21-30. https://doi.org/10.1016/j.ssi.2016.06.001.

(34) Rodríguez-Carvajal, J. Recent Advances in Magnetic Structure Determination by Neutron Powder Diffraction. Phys. B Condens. Matter 1993, 192 (1), 55-69. https://doi.org/10.1016/0921-4526(93)90108-I.

(35) Mitchell, J. F.; Argyriou, D. N.; Potter, C. D.; Hinks, D. G.; Jorgensen, J. D.; Bader, S. D. Structural Phase Diagram of La1-xSrxMnO3 $+\delta$ : Relationship to Magnetic and Transport Properties. Phys. Rev. B 1996, 54 (9), 6172-6183. https://doi.org/10.1103/PhysRevB.54.6172.

(36) Andersen, I. G. K.; Andersen, E. K.; Norby, P.; Skou, E. Determination of Stoichiometry in Lanthanum Strontium Manganates(III)(IV) by Wet Chemical Methods. J. Solid State Chem. 1994, 113 (2), 320-326. https://doi.org/10.1006/jssc.1994.1377.

(37) Poulsen, F. W. Defect Chemistry Modelling of Oxygen-Stoichiometry, Vacancy Concentrations, and Conductivity of $(\mathrm{La} 1-\mathrm{xSrx}) \mathrm{YMnO} 3 \pm \delta$. Solid State Ion. 2000, 129 (1), 145-162. https://doi.org/10.1016/S0167-2738(99)00322-7.

(38) Imada, M.; Fujimori, A.; Tokura, Y. Metal-Insulator Transitions. Rev. Mod. Phys. 1998, 70 (4), 1039-1263. https://doi.org/10.1103/RevModPhys.70.1039.

(39) Urushibara, A.; Moritomo, Y.; Arima, T.; Asamitsu, A.; Kido, G.; Tokura, Y. InsulatorMetal Transition and Giant Magnetoresistance in La1-xSrMnO3. Phys. Rev. B 1995, 51 (20), 14103-14109. https://doi.org/10.1103/PhysRevB.51.14103.

(40) Martin, M. C.; Shirane, G.; Endoh, Y.; Hirota, K.; Moritomo, Y.; Tokura, Y. Magnetism and Structural Distortion in the La0.7Sr0.3MnO3 Metallic Ferromagnet. Phys. Rev. B 1996, 53 (21), 14285-14290. https://doi.org/10.1103/PhysRevB.53.14285.

(41) Adler, S. B. Factors Governing Oxygen Reduction in Solid Oxide Fuel Cell Cathodes. Chem. Rev. 2004, 104 (10), 4791-4844. https://doi.org/10.1021/cr020724o.

(42) De Souza, R. A.; Kilner, J. A.; Walker, J. F. A SIMS Study of Oxygen Tracer Diffusion and Surface Exchange in La0.8Sr0.2MnO3+ $\delta$. Mater. Lett. 2000, 43 (1), 43-52. https://doi.org/10.1016/S0167-577X(99)00228-1. 
(43) De Souza, R. A.; Kilner, J. A. Oxygen Transport in La1-xSrxMn1-yCoyO3 $\pm \delta$ Perovskites: Part II. Oxygen Surface Exchange. Solid State Ion. 1999, 126 (1), 153-161. https://doi.org/10.1016/S0167-2738(99)00228-3.

(44) Druce, J.; Téllez, H.; Burriel, M.; Sharp, M. D.; Fawcett, L. J.; Cook, S. N.; McPhail, D. S.; Ishihara, T.; Brongersma, H. H.; Kilner, J. A. Surface Termination and Subsurface Restructuring of Perovskite-Based Solid Oxide Electrode Materials. Energy Environ. Sci. 2014, 7 (11), 3593-3599. https://doi.org/10.1039/C4EE01497A.

(45) Hess, F.; Staykov, A.; Yildiz, B.; Kilner, J. Solid Oxide Fuel Cell Materials and Interfaces; 2018; p 1. https://doi.org/10.1007/978-3-319-50257-1_132-1.

(46) Huber, A.-K.; Falk, M.; Rohnke, M.; Luerssen, B.; Amati, M.; Gregoratti, L.; Hesse, D.; Janek, J. In Situ Study of Activation and De-Activation of LSM Fuel Cell Cathodes Electrochemistry and Surface Analysis of Thin-Film Electrodes. J. Catal. 2012, 294, 7988. https://doi.org/10.1016/j.jcat.2012.07.010.

(47) $\mathrm{Wu}$, Q.-H.; Liu, M.; Jaegermann, W. X-Ray Photoelectron Spectroscopy of La0.5Sr0.5MnO3. Mater. Lett. 2005, 59 (16), 1980-1983. https://doi.org/10.1016/j.matlet.2005.01.038.

(48) Decorse, P.; Caboche, G.; Dufour, L.-C. A Comparative Study of the Surface and Bulk Properties of Lanthanum-Strontium-Manganese Oxides $\mathrm{La} 1-\mathrm{xSrxMnO} 3 \pm \delta$ as a Function of Sr-Content, Oxygen Potential and Temperature. Solid State Ion. 1999, 117 (1), 161-169. https://doi.org/10.1016/S0167-2738(98)00260-4.

(49) Caillol, N.; Pijolat, M.; Siebert, E. Investigation of Chemisorbed Oxygen, Surface Segregation and Effect of Post-Treatments on La0.8Sr0.2MnO3 Powder and ScreenPrinted Layers for Solid Oxide Fuel Cell Cathodes. Appl. Surf. Sci. 2007, 253 (10), 4641-4648. https://doi.org/10.1016/j.apsusc.2006.10.019.

(50) Fearn, S.; Rossiny, J. C. H.; Kilner, J. A.; Evans, J. R. G. Measurement of Oxygen Transport in La0.8Sr0.2MnO3 Perovskite Grains. Solid State Ion. 2012, 211, 51-57. https://doi.org/10.1016/j.ssi.2012.01.029. 